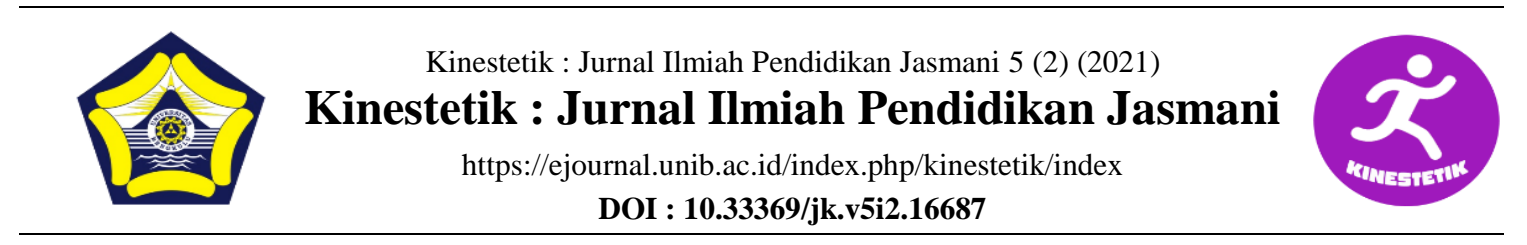

\title{
IMPLEMENTATION OF PHYSICAL EDUCATION LEARNING IN PUBLIC JUNIOR HIGH SCHOOLS DURING THE COVID 19 PANDEMIC IN LUBUKLINGGAU CITY
}

\author{
Tri Turnadi', Muhammad Kristiawan ${ }^{2}$, Rambat Nur Sasongko ${ }^{3}$, Bogy Restu Ilahi ${ }^{4}$ \\ ${ }^{1}$ SMAN 2, Education Office, Lahat Regency, South Sumatra, Indonesia. \\ ${ }^{23}$ Education Science, Postgraduate, FKIP, Bengkulu University, Bengkulu City, Indonesia. \\ ${ }^{4}$ Penjas, FKIP, Bengkulu University, Bengkulu City, Indonesia.
}

\begin{tabular}{l} 
Article Info \\
\hline Article History: \\
Received: June 2021 \\
Revised: June 2021 \\
Accepted: June 2021 \\
Available online: June 2021
\end{tabular}

Keywords:

Implementation, Learning, Physical Education

\begin{abstract}
Research on the implementation of physical education learning at State Junior High Schools during the Covid 19 pandemic in Lubuklinggau City. The subjects of this study involved physical education teachers and students in state junior high schools in Lubuklinggau City. The data analysis technique used a qualitative descriptive analysis. Collecting data using observation, questionnaires, and interviews. Based on the results of the research data analysis above, it can be seen from the implementation of Physical Education learning at State Junior High Schools during the Covid 19 pandemic in Lubuklinggau City, which has a percentage of (50.20\%) for Physical Education teachers with moderate criteria and for students $(67.03 \%)$ with criteria good. The results obtained through observation, questionnaires and interviews.
\end{abstract}

Corresponding address: Bandar Jaya, Kec. Lahat, Kabupaten Lahat, ISSN 2685-6514 (Online) Sumatera Selatan

* Corresponding email: triturnadi123@gmail.com 


\section{INTRODUCTION}

PJOK is a field of study related to human movement, physical and psychological development. PJOK is one of the compulsory subjects in schools. According to Nopiyanto, et al (2019: 24) that physical education is education through physical activities which can be in the form of games, sports, adventure activities and recreation. PJOK plays an important role in fostering and developing both individuals and groups in upholding growth and physical and spiritual development. PJOK is an important part of the development of students to achieve overall educational goals, as well as a means of realizing the goals of national development through student achievement in the field of sports.

According to (Bakhtiar, 2015)Learning movement skills is aimed at children being able to master skills in various sports. Although many parts related to physical fitness are included in the physical education program to improve children's health, physical education teachers are still considered to have a unique responsibility, namely developing movement skills. The main goal in teaching physical education is the development of movement skills, so that children can and want to participate in activities sport even later throughout his life.

The current problem from the impact of the Covid 19 pandemic in 2020 in Indonesia is starting to penetrate the world of education, the central and regional governments provide policies to close all educational institutions. This was done in an effort to prevent the spread of the corona virus. It is hoped that with all educational institutions not carrying out activities as usual, this can minimize the spread of the Covid 19 disease. The same thing has also been done by various countries affected by the Covid 19 disease, lockdown or quarantine policies are carried out in an effort to reduce the interaction of many people who can provide access to the spread of the corona virus. The policies taken by many countries, including Indonesia, are closing all educational activities,(Darmalaksana et al., 2020)

According to (Dimara, nd)Education is a normative effort that refers to noble values, which are part of the life of the nation, with which these values can be continued through the transfer of education in both aspects of knowledge (cognitive), attitudes (affective), and skills (psychomotor). Education guides humans to become more mature intellectually, morally and socially, in this context education is the preserver of culture. Education has an important role, whether we realize it or not, education will produce humans who respect their own dignity.

According to (Estrada et al., 2019)Teacher is a person whose job or livelihood or teaching profession, so that a physical education teacher can be interpreted as a person whose job or profession teaches physical education subjects. The main task of the teacher is how to condition a pleasant learning environment so that it can arouse the curiosity of all students so that their interest and desire to learn grows.

According to (Parmo, P., Sugihartono, T., \& Pujianto, 2014) Physical fitness is closely related to the child's ability to complete daily tasks and learning achievement at school, because indirectly children will be able to complete their tasks properly and smoothly, through physical education, sports and health, students will have knowledge about the importance of physical fitness, in addition. will also develop the ability of students' physical 
conditions to be better, so that students will have good endurance.

\section{METHODS}

This type of research used in this research is qualitative research. According to(Prof. dr. Sugiyono, 2013)that this research uses a descriptive approach. Descriptive research is a form of research that describes natural and man-made phenomena. Each research subject is only observed once and measurements are made of the status of the subject's variables at the time of examination.

(Prof. dr. Sugiyono, 2013)) that the research subject is something that is being researched by either person, object, or institution (organization). The subjects in this study were State Junior High Schools in Lubuklinggau City, as many as 8 SMP in Lubuklinggau City representing each District.

This research was conducted in the city of Lubuklinggau, the data collection technique used in the process of data collection in this study was an observational survey, the observation sheet was the physical education teacher activity observation sheet consisting of ten question items. Teachers will get good grades if they have carried out at least 7 observation items (Pujianto and Insanistyo, 2013: 58), then data collection techniques use a questionnaire or questionnaire, and documentation.

Data analysis techniques are very important in research because data analysis can provide meaning that is useful in solving research problems. Research technique model of Miles and Huberman (1984) in(Prof. dr. Sugiyono, 2013), argued that the activities in qualitative data analysis were carried out interactively and continued to completion, so that the data was saturated. Activities in data analysis, namely data reduction, display data, and conclusion.

1. Data reduction

The amount of this data obtained in the field is quite large, so it is recorded carefully and in detail. Reducing data means summarizing, choosing the main things, focusing on the things that are important, looking for themes in the main and removing unnecessary. The data that has been reduced will provide a clear picture and make it easier for researchers to carry out further data collection, and search for it if necessary. Data reduction can also be assisted by electronic devices such as computers by providing codes on certain aspects. With reduction, the researcher summarizes, retrieves important data, makes categorization based on uppercase, lowercase, and numbers.

2. Display data (presentation of data)

After the data is reduced, the next step is to display the data. Display in qualitative research is usually carried out in the form of including: brief descriptions, charts, relationships between categories,flow chart etc. Miles and Huberman inside(Prof. dr. Sugiyono, 2013)states that "the most frequent from display data for qualitative research data in the pas has been narrative text", meaning that the most frequent data in qualitative research is presented with narrative text. Apart from being in a narrative form, data displays can also be in the form of graphs, matrices, networks.

3. Conclusion Drawing / Verification

The next step, the third work step, is drawing conclusions and verification. The initial conclusions determined are still provisional, and will change if supporting evidence is found at the next data collection stage. However, if the conclusions have indeed been supported by valid and consistent evidence, then the researcher returns to 
the field to collect data. So the conclusion that is put forward is a creative conclusion (can be trusted).

The data collection technique in this study used descriptive analysis. Descriptive analysis is an analysis that is used to analyze data by describing or describing the collected data as it is without making generalized conclusions or generalizations. Furthermore, interpretations can be carried out as a discussion of the problems posed in the form of a percentage. Sudjono inside(Gulo, 2013) the formula for calculating the relative frequency (percentage) is as follows:

$$
\mathrm{P}=\mathrm{X} 100 \% \frac{F}{N}
$$

Information :

$\mathrm{P} \quad$ : percentage number

$\mathrm{F} \quad$ : the number of frequencies

$\mathrm{N}$ :number of subjects

(responsden)

Furthermore, data processing will be assisted by a Microsoft Excel computer program to make it easier.

\section{RESULTS AND DISCUSSION}

\section{A. Observation}

Based on the observations that have been made by the researcher, observing the performance in the form of a questionnaire distributed to schools as many as 8 respondents with 10 questions, the results obtained from the analysis can be seen in the image diagram as follows.

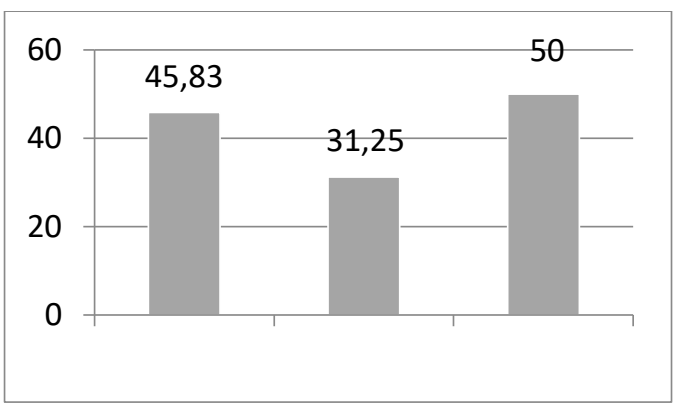

Based on the data in the image above, data on the opening indicator $(45.83 \%)$ were obtained, the core indicator had a percentage $(31.25 \%$ ), while the closing indicator $(50 \%)$, with an average percentage value of $(41.25 \%)$. with moderate criteria. So it can be concluded that the observation sheet during the Covid 19 pandemic in Lubuklinggau City has quite good criteria with a percentage $(41.25 \%)$.

\section{B. Questionnaire}

a. Physical education teacher

Based on a questionnaire distributed directly to schools as many as 8 respondents with 20 statements, the results of the analysis can be seen in the

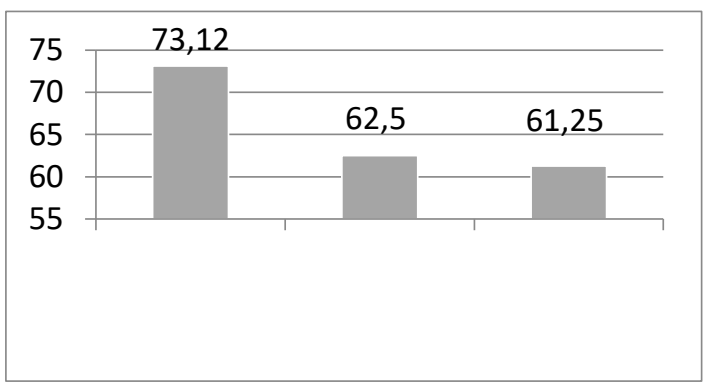

following figure:

Based on the results of the analysis of the research data in the picture above, it can be seen that the implementation of Physical Education learning at State Junior High Schools during the Covid 19 pandemic in Lubuklinggau City with an indicator of the learning process with a percentage (73.12\%), the implementation of online Physical Education learning uses competency in facilities and infrastructure with percentage $(62.5 \%)$, the implementation of Physical Education learning with learning support competencies with a percentage $(61.25 \%)$, So it can be concluded that the implementation of Physical Education learning in State Junior High Schools during the Covid 19 pandemic in Lubuklinggau City has good criteria with a percentage $(65.62 \%)$. 


\section{b. Students}

Based on a questionnaire distributed to schools of 24 respondents with 20 statements, the results of the analysis can be seen in the following figure.

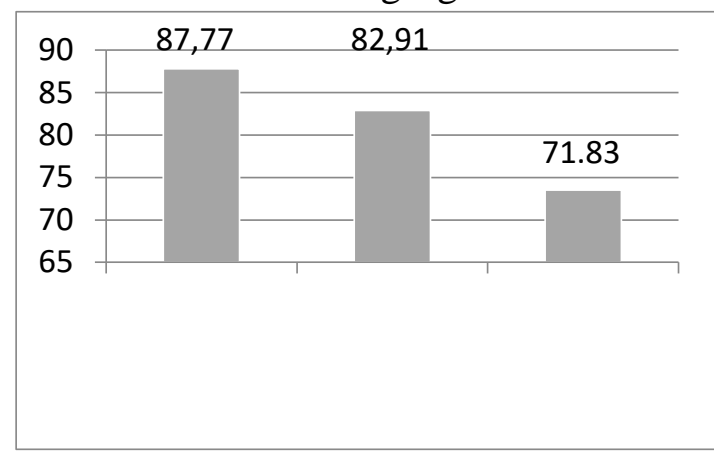

Based on the results of the analysis of the research data in the picture above, it can be seen that the implementation of physical education learning at State Junior High Schools during the Covid 19 pandemic in Lubuklinggau City with an indicator of the learning process with a percentage $(87.77 \%)$, the implementation of online learning using the competency of facilities and infrastructure $(82.91 \%)$, the implementation of Physical Education learning with learning support competencies with a percentage $(71.83 \%)$. So it can be concluded that the implementation of physical education learning at State Junior High Schools during the Covid 19 pandemic in Lubuklinggau City has very good criteria with a percentage $(80.83 \%)$.

\section{Interview}

a. Physical education teacher

In this study, data collection was also carried out by means of interviews, using unstructured interviews with 12 respondents, namely the Physical Education teacher, with 10 questions, the results can be seen in the following diagram:

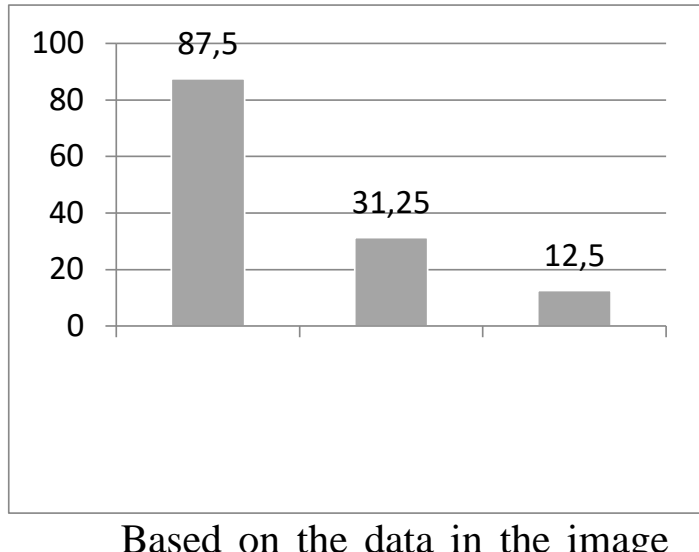

Based on the data in the image above, data on the learning process $(12.5 \%)$ were obtained, the facilities and infrastructure indicators had a percentage $(31.25 \%)$, while the learning support indicators $(87.5 \%)$, with an average percentage value of $(43.75 \%)$ with medium criteria. So it can be concluded that the physical education teacher interview sheet during the Covid 19 pandemic in Lubuklinggau City has quite good criteria with a percentage $(43.75 \%)$.

\section{b. Students}

Based on interviews that have been conducted at public junior high schools in Lubuklinggau City with representatives of 12 students as answers to this interview, it can be seen in the following figure.

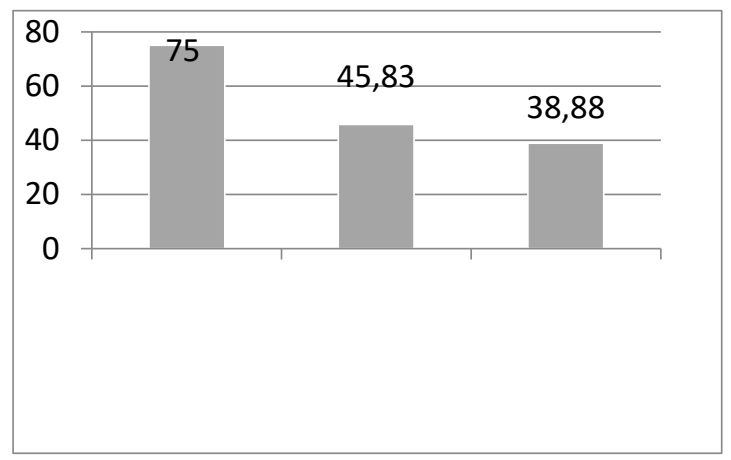

Based on the data in the image above, data on the learning process (38.88\%) were obtained, the facilities and infrastructure indicators had a percentage $(45.83 \%)$, while the learning 
support indicators (75\%), with an average percentage value of $(53.24 \%)$ with medium criteria. So it can be concluded that the student interview sheets during the Covid 19 pandemic in Lubuklinggau City had quite good criteria with a percentage (53.24\%).

\section{DISCUSSION}

Hresults of the questionnaire, Research shows the implementation of Physical Education learning at State Junior High Schools during the Covid 19 pandemic in Lubuklinggau City for Physical Education teachers is $65.62 \%$ which is included in the good criteria. Meanwhile, the implementation of Physical Education learning for students is $80.83 \%$ which is a very good criterion.

According to (Jayul \& Irwanto, 2020)Online learning is learning that utilizes multimedia technology, video, virtual classes, animated online text, voice messages, e-mail, conference calls, and online streaming video learning can be done massively with an unlimited number of participants, can be done for free or for a fee. This is done to avoid direct contact between educators and students where a conventional or face-to-face learning system can expand the spread of the Covid-19 virus, the learning process is going well.

The results of observations and interviews conducted by researchers as well as filling out existing questionnaires in schools with Physical Education teachers and student representatives in each sub-district representing the SMP, the results of observations that have been carried out get a percentage of $(41.25 \%)$ with moderate / sufficient criteria. good. While the results of the interviews conducted by researchers got a percentage of $(43.75 \%)$ for Physical Education teachers with moderate criteria, and for students a percentage of $(53.24 \%)$ with moderate criteria.

\section{CONCLUSIONS}

Based on the results of the research and discussion obtained, it can be concluded as follows: The results of the questionnaire on the implementation of Physical Education learning at State Junior High Schools during the Covid 19 pandemic in Lubuklinggau City from 3 categories, namely indicators of the learning process, indicators of facilities and infrastructure, indicators of supporting learning as well as results the percentage of the three categories is to get conclusions in good criteria. These results prove that the implementation of physical education learning in public junior high schools during the Covid 19 pandemic in Lubuklinggau City is in the form of assignments in the form of written questions given to students by Physical Education teachers and done from home.

Based on all the research results that have been conducted by researchers, the results obtained according to the results of observations are in the medium category with a percentage (41.25), the results of the interview are in a moderate category with a percentage (43.75), and the results from the questionnaire have a good category with a percentage (65.62). So the researcher has determined that the results of the 3 research guidelines above have a moderate category with a percentage (50.20), it can be concluded that physical education learning during the Covid 19 pandemic in Lubuklinggau City according to the Physical Education teacher is in the moderate category. As for the results of students taken from the results of interviews with the medium category with a percentage of (53.24), while the results of the student questionnaire that have been conducted 
have a good category with a percentage (80.83).

\section{SUGGESTION}

Based on the research conclusions, suggestions that can be submitted are:

1. Physical education teachers must adjust to students 'abilities in doing Physical Education learning online, learning that is carried out from home must of course be able to improve students' fitness, motor skills, and values that include cognitive, effective and social aspects.

2. Physical education teachers are expected to provide motivation, input and conduct occasional evaluations to find out if students are learning online.

3. It is hoped that the Physical Education teacher will make a form of learning through videos that can be used to demonstrate movements in the psychomotor realm, and students are also expected to be able to mimic the movements that the Physical Education teacher has given and done from home.

\section{REFERENCES}

Bakhtiar, S. (2015). Merancang Pembelajaran Gerak Dasar Anak. In Merancang Pembelajaran Gerak Dasar http://repository.unp.ac.id/65/ Anak.

Darmalaksana, W., Hambali, R. Y. A., Masrur, A., \& Muhlas. (2020). Analisis Pembelajaran Online Masa WFH Pandemic Covid-19 sebagai Tantangan Pemimpin Digital Abad 21. Karya Tulis Ilmiah (KTI) Masa Work From Home (WFH) Covid-19 UIN Sunan Gunung Djati Bandung Tahun 2020, 1(1), 1-12.

Dimara, F. H. (2010). Bentuk dan
Implementasi Nilai Pendidikan Karakter dalam Cerita Mitos Manarmakeri Suku Biak Numfor Provinsi Papua (Vol. 6285354656, pp. 33-56).

Estrada, E., Pujianto, D., \& Arwin, A. (2019). Persepsi Kepala Sekolah Terhadap Kinerja Guru Pjok Sekolah Menengah Atas Negeri Di Kota Bngkulu. Kinestetik, 3(2), 198-207. https://doi.org/10.33369/jk.v3i2.891 5

Gulo, w. (2013). Metodologi Penelitian. Hartono, R., Pujianto, D., \& Arwin, A. (2019). Persepsi Guru Penjas Terhadap Kompetensi Mahasiswa Magang 2 Prodi Penjas Fkip Unib Di Smp Negeri Kota Bengkulu Tahun 2018. Kinestetik: Jurnal Ilmiah Pendidikan Jasmani, 3(2), 165-173.

Hanaf, 2011. Subjek dan objek penelitian.

Irwanto. 2020. Model Pembelajaran Daring Sebagai Alternatif Proses Kegiatan Belajar Pendidikan Jasmani di Tengah Pandemi Covid-19 halaman 191

Jayul, A., \& Irwanto, E. (2020). Model Pembelajaran Daring Sebagai Alternatif Proses Kegiatan Belajar Pendidikan Jasmani di Tengah Pandemi Covid-19 Achmad. Jurnal Pendidikan Kesehatan Rekreasi, 6(2), 190-199.

Nopiyanto Dkk. (2019) . Filsafat Pendidikan Jasmani Dan Olahraga. Bengkulu: Zara Abadi.

Pardosi, T. I., Syafrial, S., \& Bogy, R. I. Studi Analisis Pencapaian Prestasi Atlet Bulutangkis Di Klub Pbsi Kota Bengkulu (Doctoral dissertation, Universitas Bengkulu).

Parmo, P., Sugihartono, T., \& Pujianto, D. (2014). Hubungan Tingkat Kebugaran Jasmani Dengan Prestasi Belajar Siswa Sma Negeri 1 Ujan Mas Kecamatan Ujan Mas 
Kabupaten

Kepahiang.

Repository.Unib.Ac.Id.

Pujianto, D dan Insanistyo, B (2013).

Dasar-Dasar Penelitian

Pendidikan Jasmani. Bengkulu.

FKIP Universitas Bengkulu.

Prof. dr. sugiyono. (2013). Prof. dr. sugiyono, metode penelitian kuantitatif kualitatif dan r\&d.

Winarni, Endang Widi. 2018. Teori dan Praktik Penelitian Kuantitatif, Kualitatif, PTK dan R\&D.

Bumi Aksara: Jakarta, halaman 192 